\title{
Subglottic Cancer pT2 TNM Finding v6 and v7
}

National Cancer Institute

\section{Source}

National Cancer Institute. Subglottic Cancer pT2 TNM Finding v6 and v7. NCI Thesaurus. Code C64718.

Subg lottic cancer with tumor extending to vocal cord(s) with normal or impaired mobility. (from AJCC 6th and 7th Eds.) 